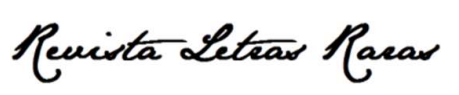

ISSN: $2317-2347$ - v. 10, n. 3 (2021)

Todo o conteúdo da RLR está licenciado sob Creative Commons Atribuição 4.0 Internacional

\title{
Pingo na goela
}

Felipe Augusto Ferreira Feijão*

Graduado em Filosofia pela Universidade Federal do Ceará.

iD http://orcid.org/0000-0002-0170-075X

Recebido em: 12 abr. 2021. Aprovado em: 13 mai. 2021.

Como citar esta produção artística:

FEIJÃO, Felipe Augusto Ferreira. Pingo na goela. Revista Letras Raras, p. 369-370, v. 10, n. 3, set. 2021.

O dia todo de barriga vazia. Rodando sem destino. Ando demais. Asfalto quente, calçada quente, é só concreto. Aí tem vez que arranjo um canto na sombra duma árvore, numa praça, num lugar que vejo que dá pra ficar, porque tem gente que enxota a gente que nem bicho. Aí com o estômago sem nada me resta pedir.

Estendo a mão pra um na parada de ônibus "favor, uma moeda pra inteirar o almoço". Na saída da loja, "favor, uma moeda pro café da manhã". "Favor, uma moeda pra inteirar a passagem." Tem vez que peço sério mesmo, mas tem vez que é pra escapar no vício. Por incrível que pareça, quando é pro vício, eu apuro mais que quando é pra encher o bucho. Não vou ficar é com a consciência pesada. Eles que têm tem mais é que dar a nós.

Pra dormir, tem calçadão bom. Mas é sempre esperto. Qualquer coisa olho aberto e partir pra defesa. Quando chove é que é ruim. Já mais ou menos acostumado. Um bom tempo nisso.

Teve uma vez eu tava pedindo no sinal. $O$ sol me queimando. Tem uns que viram é a cara pra nós. Não baixa vidro. Outros xingam. Mas, se ficar um tempo, dá pra pegar um trocado. Aí diminuiu o movimento dos carros. Parou uma dona toda arrumada num carrão, 0 vidro baixo, ela mexendo no celular. Fui na intenção de pedir "favor, uma moeda", nessa hora eu gosto de fazer cara feia e passar a mão na barriga pra convencer mais. A dona toda distraída. Enfiei a mão pra dentro e rápido corri com o celular. Só ouvia os gritos. Mas corri tanto, tanto mais tanto, que escapei. Tanto do linchamento, porque o povo não pega leve com o nosso coro como da

\section{$\triangle$ faffeijao@gmail.com}




\section{Peuista Leteas Pacas}

ISSN: 2317-2347 - v. 10, n. 3 (2021)

Todo o conteúdo da RLR está licenciado sob Creative Commons Atribuição 4.0 Internacional

polícia. Já fui pra jaula mais de vez já. Não achei tão ruim. Mas não gosto. Melhor tá zanzando mesmo.

O cara disse que, se eu ficasse repassando pra ele, ele me dava agrado além do acerto normal. Fiquei um tempo fazendo isso. Mas sempre o risco é grande.

Quando tô no vício, durmo muito, como pouco ou nada. Me aquieto num canto. Só ter cuidado pra não mexerem comigo. Mas não é sempre. É fase. Passa uns dias e volto a pedir. Pro almoço, pro café, como se eu fosse comer como era pra ser mesmo, ou pra passagem, que é pra lugar nenhum.

A chinela vive rala, o calcanhar pegando fogo. Me viro como posso. Agora dei pra emagrecer. E não tenho mais a fome que tinha, acho é bom. Ah, e uma moleza horrivel no corpo. E ainda tem as dores na barriga, na parte aqui debaixo. É fase. Ando até um canto e, quando tô ruim, passo é tempo por ali.

Canso de tá sem nada no bolso, mas mesmo assim vou no cara gente boa. Fico por lá, faço uma média. Aí mando, só um pingo na goela. Ele colabora, pendura a conta, facilita. Os dois dedinhos viram duas garrafas. Ajudo com qualquer coisa quando não caio total e saio fora. Difícil cair no vício na companhia de alguém. Sou só e sempre fui. Mas não vou mentir. Tem vez que aparece. Aí aproveito. É fase. 